\title{
Monetary Policy Impact on Stock Return: Evidence from Growing Stock Markets
}

\author{
Raksha Bissoon, Boopen Seetanah, Reena Bhattu-Babajee, Narvada Gopy-Ramdhany*, Keshav Seetah \\ University of Mauritius, Moka, Mauritius \\ Email: *n.gopy@uom.ac.mu
}

How to cite this paper: Bissoon, R., Seetanah, B., Bhattu-Babajee, R., Gopy-Ramdhany, N. and Seetah, K. (2016) Monetary Policy Impact on Stock Return: Evidence from Growing Stock Markets. Theoretical Economics Letters, 6, 1186-1195. http://dx.doi.org/10.4236/tel.2016.65112

Received: September 2, 2016 Accepted: October 19, 2016 Published: October 21, 2016

Copyright $\odot 2016$ by authors and Scientific Research Publishing Inc. This work is licensed under the Creative Commons Attribution International License (CC BY 4.0).

http://creativecommons.org/licenses/by/4.0/

\begin{abstract}
This study investigates the impact of monetary policies on stock markets based on a sample of five open countries with growing stock market over the period 2004 to 2014. Using a random effect model for the panel regression coupled with a panel vector error correction model to study the short term and long term relationship between the variables, the findings reveal a negative relation between interest rate and stock return and a direct link between money supply and stock return. The results confirm that both in the short run and long run monetary variables explain changes in stock return.
\end{abstract}

\section{Keywords}

Monetary Policy, Rate of Interest, Money Supply, Stock Return

\section{Introduction}

Financial markets and more specifically stock markets are considered as being highly sensitive to changes occurring in the economy. Monetary policies are usually undertaken to restore or maintain stability within an economy and such policies can either be expansive or restrictive with Central banks using interest rates and money supply as monetary policy instruments. Stock valuation is done by using the future cashflows associated with the stocks and discounting at the appropriate interest rate, which is estimated by considering the general level of interest rates prevailing in an economy. During expansive period, stock prices should normally be higher, given that the interest rates at which cashflows are discounted will be lower and also there should be a boost in economic activity. A restrictive period means higher interest rates and lower future economic activity, entailing lower stock prices.

The quantity theory of money formalizes the link relating money supply and stock prices. When there is an increase in money supply, there will be a surplus in the quan- 
tity of money and this will encourage people to demand more shares and thus cause an increase in share prices. The liquidity hypothesis also suggests a positive relationship between the variables. According to the policy anticipation hypothesis, to counter the surplus of capital in circulation, there would be a tightening of credit condition, mainly through a rise of interest rates and this would result in a fall in stock prices. The expected inflation hypothesis also predicts an inverse relationship between the two variables.

There is a number of empirical works on the hypothesized link. Earlier work from Jensen and Johnson [1] who studied the long term and quarterly behavior of monetary policy impact on stock return from 1962 to 1991 in the U.S found that stock returns increase during expansive monetary periods. Subsequently using VAR estimates Thorbecke [2] found that a restrictive monetary policy decreases stock prices, while an expansionary monetary policy raises stock prices. Jefferis and Okeahalam [3] found similar results on Johannesburg, Botswana and Zimbabwe stock exchanges and claimed that higher interest rates tend to reduce stock prices. Neri [4] also explored this impact on G-7 countries and confirmed that a restrictive policy reduces stock indices. Ioannidis and Kontonikas [5] assessed monetary policy impact in 13 OECD countries and found that monetary policy affects stock returns. More recently, Saidjada et al. [6] used Johansen cointegration approach to study how monetary policy and stock return are related in Dhaka stock exchange and their study revealed a negative relationship between price of stock and treasury rate. As such Eita [7] gives evidence that there is an indirect link between the rate of interest and equity return in Namibia, empirical results which tallied with earlier works from Gan, Lee, Young and Zhang [8]. Furthermore, the empirical work performed by Stoica O. and Diaconasu D.E. [9] gives evidence that both short term and long term interrelationship is present between interest rate and stock return in European Union Countries.

By contrast, several studies including those of Cornell [10], Pearce and Roley [11] and Sellin [12] have shown that there is an inverse link between stock return and money supply. Cornell [10] explained the link between money supply and equity return using the risk premium as a factor. Thus an increase in money demand is an indication of higher risk and investors would want a higher risk premium for the stocks; resulting in a decrease in stock prices.

It is noteworthy that some authors for instance Bordo and Jeanne [13] and Fair [14] could not find evidence that interest rate and money supply do not affect stock prices. Similarly Durham [15] also supports this view that a weak relation is present between monetary policy and stock return. Other studies from Kandir [16], Wei et al. [17], Mahmood [18] and Kraft and Kraft [19] also found no link between money supply and stock return.

A brief review of the literature indicates the presence of some mixed empirical results and has overwhelmingly focused on single country cases. Moreover, quite a number of researches have been done to assess how stock return is affected by monetary policy, in both developed and developing countries. In this study the analysis will be more fo- 
cused on the impact of monetary policies in growing stock market countries. Thus the aim of this research is to analyze how stock return is affected by monetary policy in five countries, with Mauritius representing Africa, Trinidad representing South America, Tokyo representing Asia, London representing Europe and finally Australia. These countries have a relatively well-developed financial market and their stock markets have been performing well over the past years. This research uses both static (random effect model) and a dynamic panel data framework (namely a panel vector error correction model) to study both the short term and long term relationship between the variables under study.

An important aspect of this study is that it focuses on a period including two financial crises; and thus the impact of monetary policy instruments during such tumultuous phases would be assessed. Therefore the study will enable policymakers have an idea upon how actions or inactions on their behalf will impact on the stock market.

The rest of the paper is structured as follows: Section 2 presents the research methodology and discusses the findings from both the random model and the Panel Vector autoregressive model and Section 3 concludes.

\section{Research Methodology}

In this section, a panel estimation model is being used to assess the link between stock index and monetary policy variables, using a sample of five countries, each situated in different continents namely Mauritius, London, Australia, Japan and Trinidad. The study relies on secondary data for the period 2004 to 2014, which were obtained from various sources as given in Table 1 . In the process, the effects of the financial crisis 2008 and EU crisis 2011 on the variables will also be assessed.

\subsection{Relationship Model}

To study the relationship between the variables, a panel approach similar to Alam and Uddin [20] will be used. In this study, the authors had considered the link between stock price and interest rate. To discern the impact of macroeconomic variables on stock return, money supply has also been added as an independent variable. The regression will be run using statistical software Eviews 9.

Table 1. Data sources.

\begin{tabular}{ccc}
\hline Stock Return & Mauritius & Stock Exchange of Mauritius Factbook 2015 \\
\hline London & Official Website London Stock Market \\
Trinidad & Official Website Trinidad Stock Market \\
Australia & Quandl Financial and Economic Data Website \\
Jnterest Rate & For all Countries & Official Website Japan Stock Market \\
Money Supply & Mauritius, Trinidad, Australia, Japan, & The world Bank Data Website \\
& London & The world Bank Data Website \\
\hline
\end{tabular}


In order to estimate the relationship, the fundamental model is estimated:

$$
\operatorname{lgSR}=\alpha_{0}+\alpha_{1} I R_{i t}+\alpha_{2} M S_{i t}+e_{i t}
$$

Extended Model (Dummy variable Financial Crisis)

$$
\operatorname{lgSR}=\alpha_{0}+\alpha_{1} I R_{i t}+\alpha_{2} M S_{i t}+\alpha 3 D F C_{i t}+e_{i t}
$$

Extended Model (Dummy variable Euro Crisis)

$$
\operatorname{lgSR}=\alpha_{0}+\alpha_{1} I R_{i t}+\alpha_{2} M S_{i t}+\alpha 3 D E U_{i t}+e_{i t}
$$

The dependent variable is the logarithm of stock return $(I g S R)$ and the independent variables are Interest Rate $(I R)$ and Money Supply $(M S)$.

In Equations (2) and (3) respectively, dummy variables for Financial Crisis (DFC) and Euro Crisis $(D E U)$ are used.

\subsection{Data Analysis}

The explanatory variables are tested using the panel summary unit root test. The stationary test showed that all variables in the model are I (1) process, that is stationary at level 1. The Pedroni Panel co-integration test shows that (Panel PP statistic, Panel ADF-statistic, Group PP Statistic and Group ADF Statistic) co-integration in the long term is present in the variables. The results are confirmed by the Johansen Fisher Panel Cointegration test.

\subsection{Fundamental Model}

The Hausman test suggested the use of a random model and the results are shown in Table 2.

From the results, it is observed that the coefficient for interest rate has a negative value, suggesting an inverse link between stock return and rate of interest. Since the p-value is less than $5 \%$ level of significance, it is concluded that there is a significant relationship between the two variables, suggesting that in the countries studied which have growing stock markets, interest rate impact negatively on stock return. This relationship is confirmed by previous studies such as Uddin and Alam [20], Banerjee and

Table 2. Result of random effect.

\begin{tabular}{cc}
\hline & Dependent Variable-LSR \\
\hline Variables & Random Effect \\
Cons & $8.391534(0.0000)^{*}$ \\
LIR & $-0.072418(0.0000)^{*}$ \\
LMS & $0.008368(0.1476)^{*}$ \\
R-Squared & 0.401406 \\
F-Statistic & 20.78799 \\
Prob (F-STATS) & 0.000000 \\
Durbin-Watson Statistic & 1.006350 \\
\hline
\end{tabular}

$\left[{ }^{*}\right]$ significant at $5 \%$ level of significance. 
Adhikary [21], who highlighted the presence of an indirect link between stock return and rate of interest. Gan, Lee, Yong and Zhang [8] also confirmed the existence of a long term negative association between the two variables.

The relation between total amount of money in circulation and prices of stock is significant and positive. This means that a direct link is present between equity return and money supply. Sprinkel [22], Homa and Jaffee [23], Fama [24] and Maskay [25], also confirmed the direct relationship. This is because a rise in money supply causes interest rates to fall, thus firms have to calculate the price of stock with a lower discount rate.

\subsection{Extended Model with Dummy (Financial Crisis)}

In order to find if the impact of macroeconomic variables on stock return is different in the pre or post financial crisis period, the effects of financial crisis will be integrated in the model. A dummy variable will be added in the regression, as illustrated in Equation (2). The dummy variable $D F C$ shows the impact on stock return from 2002 to 2006. This is represented by $D=0$ and the period with financial crisis is 2007 to 2014 denoted by $D=1$ for other years. The random effect estimates are summarized in Table 3 .

The p-value for IR is significant and negative at $5 \%$ significance level, implying that it has an effect on equity return in the five growing stock markets. DCF is significant and negative, meaning that financial crisis has affected the stock return in the five countries with growing stock market. However the p value for MS is not statistically significant at $5 \%$ level and this indicates that money supply had no effect on stock return when taking financial crisis into consideration. Therefore changes in total amount of money in such period had no effect in stock return.

\subsection{Extended Model with Dummy (Euro Crisis)}

The impact of the EU financial crisis 2011 on stock return is assessed by using a second dummy variable $D E U$, as illustrated in Equation (3). This dummy shows the impact on stock return from 2002 to 2010 (represented by $D=0$ ) and the period of Euro financial crisis is from 2011 to 2014 (represented by $D=1$ ) (Table 4).

Table 3. Result of Random Effect with dummy DFC.

\begin{tabular}{cc}
\hline & Dependent Variable-LSR \\
\hline Variables & Random Effect \\
Cons & $8.403321(0.0000)^{*}$ \\
IR & $-0.074431(0.0000)^{*}$ \\
MS & $0.004781(0.4069)$ \\
DFC & $-0.207561(0.0236)^{*}$ \\
R-Squared & 0.269625 \\
F-Statistic & 16.61116 \\
Prob (F-Stats) & 0.000000 \\
Durbin Watson Statistic & 1.133035 \\
\hline
\end{tabular}

$\left[{ }^{*}\right]$ significant at $5 \%$ level of significance. 
Table 4. Result of random effect with dummy DEU.

\begin{tabular}{cc}
\hline & Dependent Variable-LSR \\
\hline Variables & Random Effect \\
Cons & $8.339132(0.0000)^{*}$ \\
IR & $-0.068424(0.0000)^{*}$ \\
MS & $0.009016(0.1248)$ \\
DEU & $0.057958(0.4765)$ \\
R-Squared & 0.406330 \\
F-statistic & 13.91692 \\
Prob (F-STATS) & 0.000001 \\
DURBIN-WATSON STATISTIC & 0.994923 \\
\hline
\end{tabular}

$\left[{ }^{*}\right]$ significant at $5 \%$ level of significance.

The results indicate that there is a significant and inverse relationship between interest rate and stock return. However MS and DEU do not significantly affect stock return during the Euro Crisis period.

\subsection{Short Run and Long Run Estimates Results}

From the Johansen Fisher Panel co-integration results, it was found that there is co-integration among the variables. In order to determine the long term and short term link between the two variables and stock return, the Panel Vector error Correction model (PVECM) is subsequently used (Table 5).

The long run estimate indicates that interest rate have an inverse and significant effect on stock return; these results correspond to those obtained by Liu and Shrestha [26] who investigated the relationship between bank rate and stock price over the long term in China, using heteroscedastic co-integration method. As regards to money supply, the results show a positive significant impact on stock return in the long run. The results obtained are similar to that obtained by Nawaz Ahmad [27], who studied the association between money supply and stock prices in Pakistan and confirmed the existence of a long run relationship between the variables.

The results show that in the short term, interest rate has a negative and significant impact on stock return. This is consistent with Pilinkus and Boguslankas [28], who concluded that in the short term, interest rates affect stock prices negatively. In the short term, money supply has a positive and significant impact on stock return. The results are similar to that of Husain and Mahmood [18]. Eze [29] also explored the effect of monetary policy on stock indices in Nigeria using error correction model, he found that money supply determine stock return in the short run.

\subsection{Implication of Findings}

The random effect result from Equation (1) indicates an important negative link between rate of interest and stock return. This is in line with past researches from different 
Table 5. (a) P (VECM) long run estimate result; (b) P (VECM) short run estimate result.

(a)

\begin{tabular}{cc}
\hline Cointegrating Equation & Coin Equation (1) \\
\hline $\operatorname{LSR}(-1)$ & 1.000000 \\
$\operatorname{IR}(-1)$ & $-0.298347(0.09408)^{*}$ \\
$\operatorname{MS}(-1)$ & $0.492602(0.08875)^{*}$ \\
C & -9.991621 \\
\hline
\end{tabular}

$\left[{ }^{*}\right]$ significant at $10 \%$ level of significance.

(b)

\begin{tabular}{cc}
\hline Error Correction & D (LSR) \\
\hline Coin Equation (1) & $-0.021818(0.01148)$ \\
D $((\operatorname{LSR})(-1))$ & $0.012340(0.13765)$ \\
D (IR $(-1))$ & $-0.032892(0.01663)^{*}$ \\
D (MS $(-1))$ & $0.003894(0.00469)^{*}$ \\
C & $0.043165(0.02996)$ \\
R-Squared & 0.153835 \\
\hline
\end{tabular}

$\left.{ }^{*}\right]$ significant at $10 \%$ level of significance.

countries; Vithessonthi and Techarongrojwong [30] for Thailand, Ioannidis and Kontonikas [5] for 10 OECD countries and Neri [4] for the US. Therefore investors can use interest rate to forecast stock return. It can be concluded that in these countries interest rate is an important variable to determine stock prices. Furthermore money supply is also another factor which significantly and positively affects stock return.

When the effect of financial crisis 2007-2008 is taken into consideration there is still an inverse linkage between rate of interest and equity return. It also indicates that $D F C$ is significant and an increase in $D F C$ will cause equity return to fall. A $1 \%$ rise in $D F C$ will cause stock price to decrease by $39 \%$. During the financial crisis period there was high volatility in stock return and in US the market, the value of stocks had fallen. From the work of Ali and Muhammad [31], the financial crisis lead to volatility in stock returns. An important fact to highlight is that when financial crisis is included in the model the R Square is only $26 \%$ as compared to the normal period where it is $40.14 \%$. This means that during financial crisis monetary policy variables are not explaining the model well since equity return is affected by other factors. This financial contagion affected Mauritius, Trinidad, Japan and Australia as well. Volatility in stock market led to a reduction in investors' confidence and discouraged them to do investment. It is to be noted that money supply is not significant and this means that during the financial crisis period it did not help investors to predict stock return. When the EU crisis is taken into consideration the negative relation between stock return and interest rate continues to exist, however the coefficient of EU and Money supply are insignificant meaning that they do not explain the model. Even if Europe was affected by the euro crisis, the 
result shows that this did not affect the stock return significantly because only countries with strong trade and financial links with Europe were the most affected, such as developing countries like Kenya, Mozambique and Uganda.

When studying the impact in the long term and short term, the impact of monetary policy on equity return using the VECM analysis reveals that both money in circulation and rate of interest are important variables that can help investors to predict stock return in long run and short run. In the short run a $1 \%$ rise in repo rate causes stock return to fall by $3.2892 \%$, but in the long run the fall in stock return is $29.83 \%$. This means that interest rate affect stock return to a greater extent in the long run.

The same can be concluded for long run and short run effect of money supply on equity return. A $1 \%$ change in money supply in the short run leads to an increase in stock return by $38.94 \%$ and in the long run by $49.26 \%$. Therefore in these countries with growing stock markets, investors will be better off if they use money supply to predict stock return for the long term. It can be inferred that when total amount of money is increased in these countries stock index will eventually increase, thus firms may expect stock price to grow.

\section{Conclusions}

The study investigated the relationship between monetary policy instruments, in the form of expansive or restrictive policies or changes in money supply, and stock returns over the period 2004-2014 using both static and dynamic panel data framework. Analysis of the results showed that for the case of the random effect, both money supply and interest rate are important variables which explain fluctuation in stock return. Therefore these variables can be used by investors when making financial decision. When taking the financial crisis into consideration, it is to be noted that money supply does not explain change in stock price. However interest rate value is still significant and negative. Also in the previous research it had been declared that financial crises were responsible for the crash in stock market and this impact was felt worldwide in every continent. Additionally an important fact to highlight is that during the financial crisis people did not rely only on the bank rate in order to invest in stock market; in fact a loss in confidence was noted for banks and they were reluctant to invest. The coefficient for financial crisis shows that this impact was felt not only in London but also in Mauritius, Japan, Trinidad and Australia.

Euro crisis did not affect the stock return significantly in the five countries. Euro crisis affected mostly Ireland and countries in the European zone. In the sample chosen, even if London is included, the results indicate that the stock market of Mauritius, London, Tokyo, Trinidad and Australia were not significantly affected by the Euro crisis. However a deeper analysis could be useful, as in reality a sharp decline in the European stock market was noted, when banks in Greece did not allow individuals to withdraw cash. In Mauritius, the policy responses which were adopted post the crisis period could explain why stock returns were not affected in a profound way.

The findings from the Panel VECM clearly proved that money supply and rate of in- 
terest have important impact on equity return both in the short and the long term. Therefore, it is to be concluded that these two variables remain important tools when forecasting future return. It can be used to predict how the economy is functioning because stock market is considered to be one of the important financial institutions in an economy.

\section{References}

[1] Jensen, G.R. and Johnson R.R. (1995) Discount Rate Changes and Security Returns in the US 1962-1991. Journal of Banking and Finance, 19, 79-95. http://dx.doi.org/10.1016/0378-4266(94)00048-8

[2] Thorbecke, W. (1997) On Stock Market Returns and Monetary Policy. The Journal of Finance, 52, 635-654http://dx.doi.org/10.1111/j.1540-6261.1997.tb04816.x

[3] Jefferis, K. and Okeahalam, C. (1999) An Event Study of the Botswana, Zimbabwe and Johannesburg Stock Exchanges. South African Journal of Business Management, 30, 131-140.

[4] Neri, S. (2004) Monetary Policy and Stock Prices: Theory and Evidence. Number 513, Banca D'Italia

[5] Ioannidis, C. and Kontonikas, A. (2008) The Impact of Monetary Policy on Stock Prices. Journal of Policy Modeling, 30, 33-53. http://dx.doi.org/10.1016/j.jpolmod.2007.06.015

[6] Saidjada, K.M., Hossain, M.S. and Rahman, M.H. (2014) Effects of Monetary Policy on Capital Markets in Bangladesh. Bangladesh Bank Monetary Policy Review, 8, 50-62.

[7] Eita, J.H. (2012) Interest Rate and Stock Market Returns in Namibia. International Business \& Economics Research Journal, 3, 689-695.

[8] Gan, C., Lee, M., Yong, H.H.A. and Zhang, J. (2006) Macroeconomics Variables and Stock Market Interactions: New Zealand Evidence. Investment Management and Financial Innovations, 3, 47-53.

[9] Stoica, O. and Diaconașu, D.E. (2012) Monetary Policy and Stock Markets Evidence from EU Countries. Communications of the IBIMA, 2012, 1-11.

[10] Cornell, B. (1983) Money Supply Announcements and Interest Rates: Another View. Journal of Business, 56, 1-23. http://dx.doi.org/10.1086/296183

[11] Pearce, D.K. and Roley, V.V. (1985) Stock Prices and Economic News. The Journal of Business, 58, 49-67. http://dx.doi.org/10.1086/296282

[12] Sellin, P. (2001) Monetary Policy and the Stock Market: Theory and Empirical Evidence. Journal of Economic Surveys, 15, 491-541. http://dx.doi.org/10.1111/1467-6419.00147

[13] Bordo, M.D. and Jeanne, O. (2002) Monetary Policy and Asset Prices: Does "Benign Neglect" Make Sense? IMF Working Paper, WP/02/225.

[14] Fair, R. (2001) Estimates of the Effectiveness of Monetary Policy. Yale School of Management Working Papers, Revised 1 August 2007.

[15] Durham, J.B. (2001) The Effect of Monetary Policy on Monthly and Quarterly Stock Market Returns: Cross-Country Evidence and Sensitivity Analysis. Finance and Economic Discussion Series, 1, 1-25. http://dx.doi.org/10.2139/ssrn.293102

[16] Kandir, S.Y. (2008) Macroeconomic Variables, Firm Characteristics and Stock Returns: Evidence from Turkey. International Research Journal of Finance and Economics, Issue 16.

[17] Liao, W. and Tapsoba, S.J.-A. (2014) China's Monetary Policy and Interest Rate Liberalization: Lessons from International Experiences. IMF Working Paper, 1, 1-24.

[18] Husain, F. and Mahmood, T. (1999) Monetary Expansion and Stock Returns in Pakistan, 
The Pakistan Development Review. Pakistan Institute of Development Economics, 38, 769776.

[19] Kraft, J. and Kraft, A. (1977) Determinants of Common Stock Price: A Time Series Analysis. The Journal of Finance, 32, 417-425. http://dx.doi.org/10.2307/2326775

[20] Alam, M. and Uddin, G.S. (2009) Relationship between Interest Rate and Stock Price: Empirical Evidence from Developed and Developing Countries. International Journal of Business and Management, 4, 43-51. http://dx.doi.org/10.5539/ijbm.v4n3p43

[21] Banerjee, P.K. and Adhikary, B.K. (2009) Dynamic Effects of Changes in Interest Rates and Exchange Rates on the Stock Market Return in Bangladesh. Ritsumeikan Journal of Asia Pacific Studies, 25, 119-133.

[22] Sprinkel, B.W. (1986) Interest Rate Impact on Return for Shares. Cato Journal, 6, 365-367.

[23] Homa, K.E. and Jaffee, D.M. (1971) The Supply of Money and Common Stock Prices. The Journal of Finance, 26, 1045-1066. http://dx.doi.org/10.1111/j.1540-6261.1971.tb01747.x

[24] Fama, E.F. (1981) Stock Returns, Real Activity, Inflation, and Money. American Economic Review, 71, 545-565.

[25] Maskay, B. (2007) Analyzing the Effect of Change in Money Supply on Stock Prices. The Park Place Economist, 15, 72-97.

[26] Shrestha, K.M. and Liu, M.H. (2008) Analysis of the Long-Term Relationship between Macroeconomic Variables and the Chinese Stock Market Using Heteroscedastic Cointegration. Managerial Finance, 34, 744-755. http://dx.doi.org/10.1108/03074350810900479

[27] Nawaz, A. and Husain, F. (2006) The Relation between Stock Prices and Money Supply in Pakistan: An Investigation. Journal of Independent Studies and Research (JISR), 5, 30-32.

[28] Pilinkus, D. and Boguslauskas, V. (2009) The Short-Run Relationship between Stock Market Prices and Macroeconomic Variables in Lithuania: An Application of the Impulse Response Function. Inzinerine Ekonomika-Engineering Economics, 66, 1-9.

[29] Eze, S.O. (2011) The Effect of Monetary Policy on Stock Market Performance in Nigeria. http://www.academia.edu/20442486/The Effect of Monetary Policy on Stock Market Perf ormance in Nigeria. Nigerian Journal of Securities and Finance 142 September 2009

[30] Vithessonthi, C. and Techarongrojwong, Y.(2012) The impact of Monetary Policy Decisions on Stock Returns: Evidence from Thailand. Journal of International Financial Markets, Institutions and Money, 22, 487-507. http://dx.doi.org/10.1016/j.intfin.2012.02.003

[31] Akbar, M., Khan, S.A. and Khan, F. (2012) The Relationship of Stock Prices and Macroeconomic Variables Revisited: Evidence from Karachi Stock Exchange. African Journal of Business Management, 6, 1315-1322. 
Submit or recommend next manuscript to SCIRP and we will provide best service for you:

Accepting pre-submission inquiries through Email, Facebook, LinkedIn, Twitter, etc. A wide selection of journals (inclusive of 9 subjects, more than 200 journals)

Providing 24-hour high-quality service

User-friendly online submission system

Fair and swift peer-review system

Efficient typesetting and proofreading procedure

Display of the result of downloads and visits, as well as the number of cited articles

Maximum dissemination of your research work

Submit your manuscript at: http://papersubmission.scirp.org/

Or contact tel@scirp.org 